THE LANGUAGE OF WORDSWORTH AND COLERIDGE General Editor: N. F. Blake

Professor of English Language and Linguistics

University of Sheffield 


\section{THE LANGUAGE OF LITERATURE}

General Editor: N. F. Blake

Published titles

The Language of Shakespeare N. F. Blake The Language of Chaucer David Burnley

The Language of Wordsworth and Coleridge Frances Austin The Language of Irish Literature Loreto Todd

Further titles are in preparation

Other books by Frances Austin The Letters of William Home Clift Robert Clift of Bodmin Able Seaman 


\section{THE LANGUAGE OF WORDSWORTH \\ AND COLERIDGE}

FRANCES AUSTIN

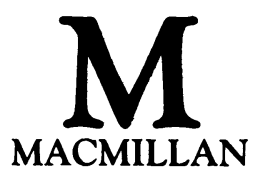


(C) Frances Austin 1989

All rights reserved. No reproduction, copy or transmission of this publication may be made without written permission.

No paragraph of this publication may be reproduced, copied or transmitted save with written permission or in accordance with the provisions of the Copyright Act 1956 (as amended), or under the terms of any licence permitting limited copying issued by the Copyright Licensing Agency, 33-4 Alfred Place, London WC1E 7DP.

Any person who does any unauthorised act in relation to this publication may be liable to criminal prosecution and civil claims for damages.

First published 1989

Published by

MACMILLAN EDUCATION LTD

Houndmills, Basingstoke, Hampshire RG21 2XS

and London

Companies and representatives

throughout the world

British Library Cataloguing in Publication Data

Austin, Frances

The language of Wordsworth and Coleridge.

-(The Language of literature).

1. Poetry in English. Coleridge, Samuel

Taylor \& Wordsworth, William, 1770-1850 -

Critical studies

I. Title II. Series

$821^{\prime} .7^{\prime} 09$

ISBN 978-0-333-43273-0 ISBN 978-1-349-20001-6 (eBook)

DOI 10.1007/978-1-349-20001-6 


\section{Contents}

Prefatory Note vii

Acknowledgements $\quad$ ix

Grammatical Terminology $\quad \mathbf{x}$

Texts and Abbreviations $\quad$ xiii

1 Introduction 1

2 Experimental Narrative Ballads $\quad 15$

3 Poems in Ballad Measure 47

4 Blank Verse-Diction 64

5 Blank Verse - Syntax 93

6 Coleridge 122

7 Analysis of Passages 169

8 Conclusion $\quad 180$

$\begin{array}{ll}\text { Notes } & 187\end{array}$

Select Bibliography and Further Reading $\quad 195$

Index 1 Textual References 199

Index 2 Literary References $\quad 201$

Index 3 Language Topics $\quad 202$ 
To my Mother and Father 


\section{Prefatory Note}

Both Wordsworth and Coleridge wrote poems for Lyrical Ballads (1798) and their names have understandably been linked ever since. They do, indeed, have many things in common, not least their reaction against eighteenth-century modes of writing poetry. Yet there are differences, too, and these determine the pattern of such a book as this. In themselves the contrasts between their poems are enlightening and help us to understand each poet better. But the difficulty is obvious from the start. Lyrical Ballads (1798) contains only four poems by Coleridge, whilst Wordsworth wrote the remaining nineteen. The collection opens with Coleridge's Ancient Mariner and many books have been written about that poem alone. Nevertheless, if we look at the collected poems of the two writers it is clear that Wordsworth wrote a great deal of first-class poetry and that Coleridge's first-class poetry consists of no more than about twenty pieces. Two of them (Kubla Khan and Christabel) are unfinished, and some would say that, magical and unique as they are, they never could have been finished. Any book about the two poets together consequently has to reflect in treatment and proportions this almost physical discrepancy in output. However, it would be wrong to judge the merit of the poems by the number of pages given to them. The quality of Coleridge's best poems is very high. This book is not a competition between the two poets but a recognition of their likenesses in some matters and their even greater and quite individual excellences - and sometimes weaknesses - in others. That Wordsworth is given more space and Coleridge less lies in the nature of their respective output of poetry. It does not mean that Wordsworth is being rated above Coleridge.

September 1987 


\section{Acknowledgements}

This book could not have been written without the help of many friends and institutions. I am particularly grateful to the librarians of the University of Southampton and the county libraries at Ringwood and especially Sherborne for dealing patiently with requests for books and articles, and to the staff of the Inter Library Loan Service.

I should like to thank the students who contributed to seminars on Wordsworth and Coleridge, and especially the 'matures' at Bishop Grosseteste, Lincoln (1969), who roused my enthusiasm for The Ancyent Marinere, and the Shaftesbury Group (1986) for their encouragement.

It is a great pleasure to acknowledge the help I have received from my former student, Valerie Milling, who has responded so promptly to enquiries about certain books not readily accessible. Dr Bernard Jones has given much time to reading my various drafts and has made many helpful suggestions. Above all, Professor Norman Blake has been tireless in answering questions and generous with encouragement, and not only during the writing of this book. I need hardly say that these people are not responsible for the shortcomings that are inevitable in a short book on so vast a subject. 


\section{Grammatical Terminology}

Inevitably in a book of this kind grammatical terms must be used. Since many readers may be unfamiliar with even 'traditional' terminology and others may be used to different terms used in the various current grammatical 'models', a few words on the usage here will not come amiss.

The basic terms for the 'parts of speech' - noun, verb, adjective, etc. - have been retained as is the practice of most current models of grammar. For explaining and describing the basic structure of sentences Systemic Grammar has generally been followed, sometimes in a modified form. In Systemic Grammar the clause is divided into four main elements: Subject, Verb, Complement and Adjunct. These are represented by the notation S VCA. Subjects and Complements (the term Complement includes both the Object and Complement of 'traditional' grammar) are often 'realised' by nominal groups. A nominal group is a group of words based round a noun which is called the 'head' of that group. An example is 'the swift flowing river with its swirling eddies', where the 'head' is the word river. All nominal groups can be used as the Subject of a sentence. Complements are also 'realised' by adjectives or adjectival phrases when they follow the verb to be or other 'copula' verbs such as seem. Examples are 'the river is deep', 'the lion looked very fierce'. Verbs are 'realised' by verbal groups. These may consist of a single verb or a verb preceded by one or more auxiliary verbs. 'John swam a hundred yards' is an example of the first kind and 'John would have been swimming today but he has a cold' of the second. Note that the verb which conveys the 'main' information (called a 'lexically full' verb) comes last in the group. An Adjunct is essentially anything which does not come under one of the other three headings. There are, 
therefore, various kinds of Adjuncts, but the basic one and that to which the notation A refers in this book is an adverb or adverbial group. Examples are 'merrily'; 'with great courage'; and 'beside the stream' in sentences such as 'he sang merrily'; 'he fought the lion with great courage'; and 'she knelt beside the stream'.

It is now customary in Systemic Grammar to discard the term 'sentence' and substitute 'clause complex'. Readers will find both terms used in this book. 'Sentence' seems too useful a term to be rejected completely but at times 'clause complex' is clearer and more precise because it indicates the clause structure of which the sentence is composed and the way in which those clauses are put together.

The term 'expansion' is a technical term. It is normally used to refer to methods of extending the clause (see M. A. K. Halliday, An Introduction to Functional Grammar, Edward Arnold, 1985, pp. 202-16) but here mostly refers to expansion of the nominal group.

One further technical term that may be unfamiliar has been used. This is 'interpersonal', again a term modified from Halliday (see IFG, pp. 332-4). It is used for comments of the poet/narrator expressing a personal opinion that occur in the text but are really external to it. Examples are 'I think'; 'it seems'; 'perhaps'; and so on.

Students will find that in most books based on Systemic Grammar the Verbal element is marked with a $\mathbf{P}$ for Predicator. As $\mathrm{V}$ seems more accessible to those unfamiliar with this grammar it has been adopted here. It is used in J. F. Wallwork, Language and Linguistics (Heinemann, 1969). Readers may consult Chapter 5 of this book for a quick guide to the structure of the four main elements of the clause. A fuller exposition of Systemic Grammar will be found in Dennis Freeborn's, $A$ Course Book in English Grammar (Macmillan, 1987). Halliday's An Introduction to Functional Grammar (see above) is a much more advanced account of Systemic Grammar written by its leading exponent and it is referred to frequently in the notes. It is of particular use for textual studies and may be of interest to those who wish to pursue the subject further. A very useful introductory book on grammar, that shows the relation of traditional grammar to Systemic Grammar, is N.F. Blake, 
Xii THE LANGUAGE OF WORDSWORTH AND COLERIDGE

Traditional English Grammar and Beyond (Macmillan, 1988). For other explanations of a rather more traditional, although upto-date, kind, the grammars of Randolph Quirk and his collaborators cannot be ignored. The latest of these is R. Quirk et al., A Comprehensive Grammar of the English Language (Longman, 1986). An earlier, somewhat shorter version is R. Quirk et al., A Grammar of Contemporary English (Longman, 1972), and a simpler version based on this is R. Quirk and S. Greenbaum, A University Grammar of English (Longman, 1973). 


\section{Texts and Abbreviations}

All poems of Wordsworth and Coleridge taken from Lyrical Ballads are quoted from Lyrical Ballads, eds R. L. Brett and A. R. Jones (London: Methuen, 1963, rev. 1965) (LB). Wordsworth's successive versions of 'The Ruined Cottage' are taken from The Ruined Cottage and The Pedlar, ed. James Butler (Ithaca, N.Y.: Cornell U.P.; Sussex: Harvester Press, 1979). References to the origins of 'The Female Vagrant' are based on The Salisbury Plain Poems of William Wordsworth, ed. Stephen Gill (Ithaca, N.Y.: Cornell U.P.; Sussex: Harvester Press, 1975). Other poems by Wordsworth are quoted from Poetical Works, eds Ernest de Selincourt and Helen Darbishire, 5 vols (Oxford: Clarendon Press, 1940-9) and the 1805 text of The Prelude, eds Ernest de Selincourt, 2nd edn. rev. Helen Darbishire (Oxford: Clarendon Press, 1959); also available in Oxford Standard Authors, 1960. The 1800 and 1802 Prefaces to Lyrical Ballads and the 1800 Note to 'The Thorn' are taken from Brett and Jones's edition of Lyrical Ballads. These may also be found in W. J. B. Owen, ed., Wordsworth's Literary Criticism (London: Routledge \& Kegan Paul, 1974), and the 1800 Preface in Vol. I of Prose Works, eds W. J. B. Owen and Jane Worthington Smyser, 3 vols. (Oxford: Clarendon Press, 1974) pp. 118-58. The 1815 Preface to Wordsworth's Poems is taken from Vol. III of Prose Works, pp. 25-39, abbreviated to $P W$. Wordsworth's letters are quoted from the seven volume edition of Chester L. Shaver, Mary Moorman and Alan G. Hill, which divides into The Early Years $(E Y)$, The Middle Years $(M Y)$ and The Later Years $(L Y)$ (Oxford: Clarendon Press, 1967-88). This edition is a revision of Ernest de Selincourt's six volume edition (Oxford: Clarendon Press, 1935-8). References to letters are followed by the equivalent volume (where relevant) and page number in de Selincourt's 
Xiv THE LANGUAGE OF WORDSWORTH AND COLERIDGE

edition. Poems of Coleridge, other than those printed in Lyrical Ballads, are quoted from The Poetical Works of Samuel Taylor Coleridge, ed. Ernest Hartley Coleridge (1975, 1st edn. 1912). Quotations from Biographia Literaria $(B L)$ are from the Everyman edition (London: Dent 1906, rev. George Watson 1965), to which page references are given. Coleridge's letters are quoted from Collected Letters of Samuel Taylor Coleridge, ed. E. L. Griggs, 6 vols. (Oxford: Clarendon Press, 1956-71).

Datings for Wordsworth's poems are mainly based on Mark L. Reed, The Chronology of the Early Years 1770-1799 (CEY) (Cambridge, Mass.: Harvard U.P., 1967) and The Chronology of the Middle Years 1800-1815 (CMY) (Cambridge, Mass.: Harvard U.P., 1975).

M. A. K. Halliday, An Introduction to Functional Grammar (London: Edward Arnold, 1985) is abbreviated to IFG. 